\title{
Need Analysis of Multi-Ball Exercise Methods Toward the Improvement of Forehand Drive Skill on Beginner Table Tennis Athletes
}

\author{
Bessy Sitorus Pane, James Tangkudung, Abdul Sukur \\ Physical Education Program \\ Jakarta State University. \\ Jakarta, Indonesia \\ bessy653@gmail.com
}

\begin{abstract}
This study aims to determine the needs for table tennis multi-ball training for table tennis practice participants at the Table Tennis Association (Persatuan Tenis Meja; abbr.: PTM) in Medan. This research uses a descriptive qualitative method. Subjects were 20 beginner athletes aged 16-21 years. The study was conducted at PTM Garuda Medan. The results show that $85 \%$ of table tennis exercises are in demand. $75 \%$ of exercises were done three times a week, $90 \%$ of respondents stated the duration of training was 90-120 minutes, and $80 \%$ deemed that the exercise was sufficient. $86 \%$ agreed that multi-ball training was necessary, $91 \%$ admitted to be given specialized training distributed multi-ball practice, $89 \%$ agreed the role of the trainer in training activities, $71 \%$ answered the trainer provided variations in forehand drive training, $89 \%$ agreed the trainer gave the method of multi-ball distributed practice. $87 \%$ believe that multi-ball training can improve forehand drive skills, $91 \%$ agree that exercise-based variations are given drill-based, and $65 \%$ agree given ball feeling games for exercise variations. $89 \%$ agree that drills use targets, $60 \%$ agree with media, $75 \%$ decided to be given the variety of multi-ball training, and $83 \%$ admitted to be given the exercise for forehand drive skills with the multiball training method.
\end{abstract}

Keywords: multi-ball, forehand drive, table tennis

\section{INTRODUCTION}

Table tennis is one of the sports that are much in demand by Indonesian people, and it has even become a popular sport in Indonesia and the world, this is because table tennis is not too difficult to follow. Table tennis is a world-famous racquet sport and the number of participation ranks second [1]. Besides table tennis is one sport that can be played by everyone without knowing the age limit. Table tennis is a sport that does not know the age limit, children and adults can play together [2].

The stroke technique is one of the main basic techniques that must be mastered in the game of table tennis, without leaving aside the other techniques. The basic technique in table tennis that is often done and mastered is forehand. A forehand is considered the basis of a punch because it is easy to learn, forehand is usually the most powerful because the body does not get in the way of a punch, unlike the backhand. Besides, the muscles used are traditionally more maximal than backhand hits [1]. If a player wants to do the basic table tennis stroke technique correctly, smoothly, and successfully, whether it is an attacking blow or a defensive shot, then he must do the punch by moving body parts such as the waist, legs, hands, and so on. This is to create movements that are harmonious when beating the ball [3].

A table tennis game is a type of game in a fast tempo. To be able to play at a fast pace, it requires speed of reaction and also good coordination of limbs. One method of training that is indispensable in playing table tennis is the multi-ball training method. Implementation of the method of multi-ball training is necessary because the participant can perform a constant stroke on the ball with the ball given by the coach continuously to form a stable punch pattern if done with the right technique.

The accuracy of punches on fast-moving targets and timings makes the right multi-ball training method to be applied in improving the skills of novice athletes. Timing has to do with the coordination of our overall body movements. Are we at the right time, in the right position, and hitting the ball at the right time [2].

The Garuda Table Tennis Association (PTM) is a Table Tennis Association in the city of Medan, having its address on Jalan Bunga Nabontar, Medan. PTM Garuda has been established in the last ten years, which is more or less in 2009. PTM Garuda has two trainers, namely Sarmadi Go Liong and Sri Surya Ningsih, in addition to being a member of GRM PTM, starting from children to adults. There are 20 members as beginner athletes who are members of PTM Garuda, consisting of 14 men and six women whose age range is sixteen to twenty-one years. The trainees are still attending high school up to tertiary institutions in Medan.

Researchers conducted field observations from 23 to 29 February 2019, saw and found that the beginner athletes of PTM Garuda were more dominant in making forehand drive hits. This can be seen from the results of observations when training on the spot. Athletes are always trained forehand drive as a mainstay to attack or to stop the opponent's game so as to get points or winning points. Also, in training sessions or warm-up when given the game, forehand drive also always beats that dominate the other shots.

Not all beginner athletes who are members of PTM Garuda Medan, amounting to 20 people, have mastered the forehand drive well. A common mistake made by 


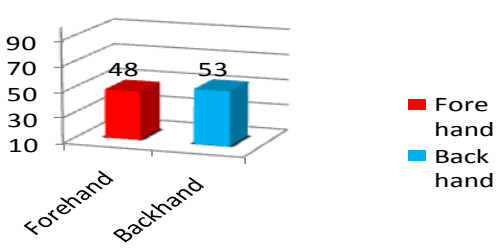

PTM Garuda Medan athletes in doing forehand drive blows is the number of balls involved on the net. In this case, the ball crosses the net but comes out of the table, and the athlete also cannot direct the ball properly.

Forehand drive skills in playing table tennis can be improved by using an effective and efficient training method that is implemented repeatedly over a long period of time. Differences in athletes in terms of reaction and timing will be a critical consideration in determining the training methods that are appropriate to the character of each athlete so that they can achieve optimal training results in accordance with their potential.

Training methods that are often used to improve skills in playing table tennis include multi-ball massed practice and distributed practice methods. The training method is one of the training methods that can be used to improve an athlete's forehand drive skills. The multi-ball training method, is a training method in which one player practices while the other players feed the ball [1]. Players will need a basket of balls. The feeder stands on the edge of the table, picking up and hitting the ball in succession at various speeds, turns, and directions that the player needs. This method is an appropriate way to learn the punch, but the disadvantage is that only one person can practice at the time. This method is often used by trainers who act as feeders.

Massed practice is a training method that is implemented without interrupting breaks between practice times until the specified time limit. Massed practice is the principle of regulating training turns where athletes perform movements continuously without interruption. Whereas distributed practice is the principle of regulating turns in training where the training time is held by taking intermittent breaks [4].

The distributed practice method is a training method that considers resting time as necessary as the time for practice. Time for rest is not a waste of time but an essential part of the process of training skills. The rest time between exercises aims for recovery. Having enough rest between exercises allows the athlete's condition to recover and be better equipped to do the next work or training.

\section{METHOD}

This research used a descriptive qualitative method. Researchers distributed questionnaire sheets to athletes and conducted interviews with trainers. This research was conducted at PTM Garuda Medan. The subjects of this study were 20 athletes who participated in training activities aged 16-21 years. This research was conducted from February 2019 to July 2019.

\section{RESULT AND DISCUSSION}

Research activities were carried out by conducting observations using observation sheets. Observations were made during the training schedule at PTM Garuda Medan. The results are as follows:
Fig. 1. The researchers' observations of forehand drives and backhand drives

From the results of the graph above shows that forehand drive $48 \%$, backhand drive $53 \%$. This is further emphasized by the distribution of needs analysis questionnaire to players who participated in the match. In the diagram above, the results of the scattered questionnaire showed that $40.50 \%$ of table tennis players did not know the training model other than that was given by the trainer, $5.50 \%$ had known the forehand drive training model, then $50.50 \%$ strongly agreed to be given the exercise model approaches playing forehand drive table tennis, then $3.20 \%$ stated they did not agree to be given a drill-based exercise model.

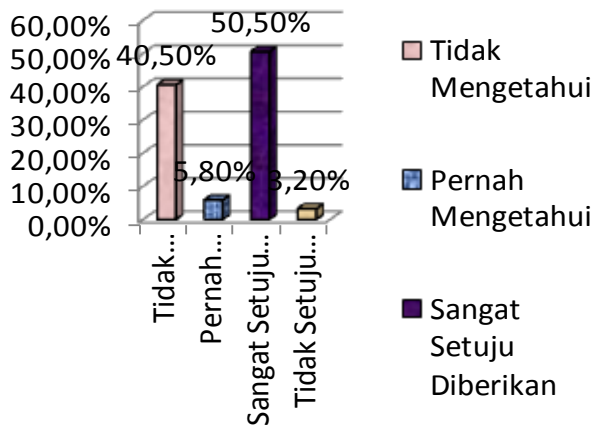

Fig. 2. Researcher's observation of the needs analysis questionnaire

\section{CONCLUSION}

The results of the analysis of the need for a multi-ball training model for table tennis forehand drive skills desired by athletes showed that $85 \%$ of table tennis exercises were in demand, $75 \%$ of exercises were done 3 times a week, $90 \%$ stated the duration of training was 90120 minutes, $80 \%$ felt the exercise had been enough, $86 \%$ agreed to be given multi-ball training, $91 \%$ agreed to be given special practice of multi-ball distributed practice, $89 \%$ agreed to the role of the trainer in training activities, $71 \%$ answered the trainer provided variations in forehand drive training, $89 \%$ agreed the trainer gave the method of multi-ball distributed practice. $87 \%$ believed that multiball training could improve forehand drive skills; $91 \%$ agreed that exercise-based variations were given drillbased; $65 \%$ agreed to be given ball feeling games for exercise variations, $89 \%$ agreed that drills used targets, $60 \%$ agreed the use of media; $75 \%$ agreed to be given the variation of multi-ball training; $83 \%$ agreed given the exercise for forehand drive skills with the multi-ball training method.

\section{REFERENCES}


[2] P. Simpson. Teknik Bermain Pingpong. Bandung: Pionir Jaya, 2007.

[3] A. Kertamanah. Teknik \& Taktik Dasar Permainan Tenis Meja. Jakarta: PT Raja Grafindo Persada, 2003.

[4] A. Suhendro. Dasar-Dasar Kepelatihan. Jakarta: Universitas Terbuka, 2004. 